\title{
CHEMICAL ANALYSIS OF WATER SOURCED FROM ODO ONA RIVER, IBADAN, SOUTH-WESTERN NIGERIA
}

\author{
FIDELIS NKESHITA ${ }^{* 1}$, ADEBOLA ADEKUNLE ${ }^{1}$, ADEBAYO ADEDEJI ${ }^{1}$ \\ ${ }^{1}$ Department of Civil Engineering, Federal University of Agriculture, Abeokuta, PMB 2240, \\ Ogun State, Nigeria
}

\begin{abstract}
The water samples were collected at three different periods of the year from locations around the Oluyole Estate Industrial hub housing many industries and located in Ibadan, South-Western Nigeria. The observed values of the concentration of Aluminium, Chromium, Iron and Sodium show varied concentrations for Sodium $(3.01-38.02) \mathrm{mg} / \mathrm{L}$, Iron $(0.8-28.68) \mathrm{mg} / \mathrm{L}$, Chromium $(0-0.38) \mathrm{mg} / \mathrm{L}$, Arsenic (Not detected) and Aluminium $(0-0.24) \mathrm{mg} / \mathrm{L}$. The results were compared with standard values of the parameters under consideration as recommended by the World Health Organization (WHO).
\end{abstract}

Keywords: Industrial effluents, metals, pollution, wastewater, water quality

\section{INTRODUCTION}

Activities resulting from manmade sources have been a major cause of contamination and pollution of streams and other water bodies [1]. These water bodies end up transporting pollutants to other sites [2,3]. Urban environmental management is one of the challenges that has continued to persist as the trend in urbanization and the resulting Industrialization continues to rise in many developing countries. One such challenge is the difficulty in managing water resources in urban areas [3 - 5].

Many industries generate products that have made life more comfortable for consumers, but the production processes involved have generated undesirable gases and liquids as waste products which eventually finds its way into receiving streams and rivers etc. [6].

Environmental pollution is a global concern, it is the instability, disorder, and discomfort to the ecosystem due to the contaminants to the natural environment. The discharge of industrial wastes that are not properly treated into water bodies can either directly or indirectly bring about water pollution [7]. The industrial wastewater, which contains harmful substances including many toxic heavy metals, toxic chemicals, pesticides and many other chemicals from a variety of industries are usually discharged in large quantities [8].

Heavy metals cause the reduction of mental developments and central nervous function as well as brain impairment. Also, excessive concentrations of heavy metals can negatively affect lungs, kidneys, liver, heart, skin, muscle, blood composition, and other vital organs for human and other living organisms [9].

The consequence of having these effluents being discharged in an aquatic environment without proper mitigating measures is the resultant production of toxic algal blooms, water quality degradation and an unstable ecosystem [10]. This research aims to determine the level of pollution using selected parameters for heavy metals.

\footnotetext{
${ }^{*}$ Corresponding author, email: nkeshitafc@ funaab.edu.ng
}

(C) 2021 Alma Mater Publishing House 


\section{MATERIALS AND METHODS}

\subsection{Description of the study area}

Oluyole Industrial estate is in Oluyole local government area of Oyo state. It is one of the major industrial layouts of Ibadan (situated at an average height of $200 \mathrm{~m}$ above mean sea level, drained by four river basins and surrounded by the secondary rainforest as well as a savannah) Oyo State, south-west of Nigeria (FigURE 1). It has an estimated population of 282,585 as stipulated by the 2006 census, and located on latitude $\left(7^{\circ} 19^{\prime} 10^{\prime \prime} \mathrm{N}, 7^{\circ} 23^{\prime} 36^{\prime \prime} \mathrm{N}\right)$ and longitude (350'36' 'E and 3 $\left.55^{\circ} 33^{\prime \prime} \mathrm{E}\right)$.

Some of the industries channel their effluents through a network of connected canals to Alaro stream which is a tributary to rivers Papa and Odo-Ona. Odo-Ona River is a major river in Ibadan that flows through the entire length of the city from north to south, though it receives water from other tributaries within the city, it has an estimated area of $81.0 \mathrm{~km}^{2}$ and flows through the low-density western part of Ibadan in a north-south direction from its source at Ido Local Government Area, where it is dammed and also flows through ApataGenga (Ibadan southwest Local Government Area) to Oluyole Local Government.

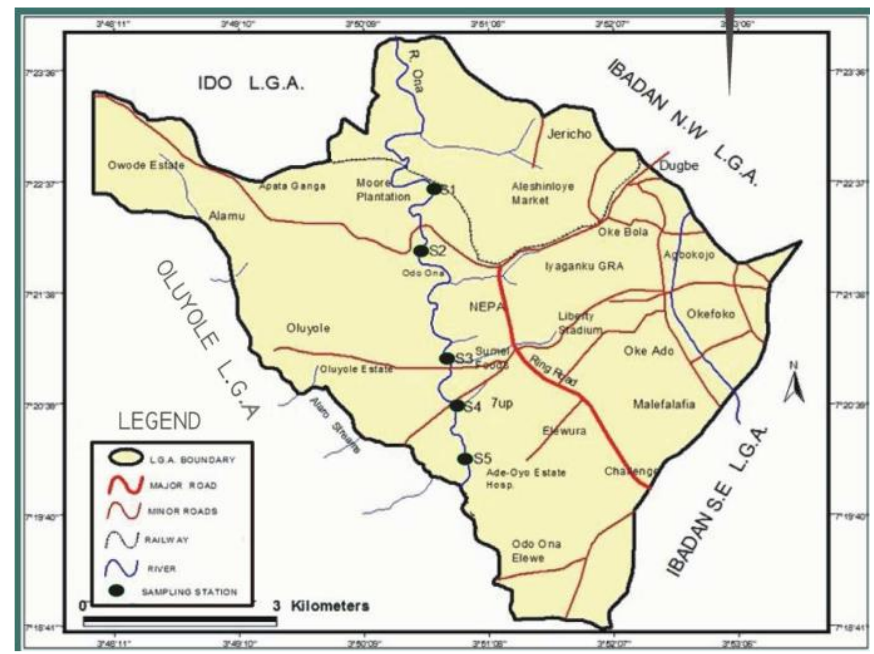

Fig. 1. Map showing the layout of Oluyole area in Ibadan and sample collection locations. Sample collection and analysis.

Water samples were collected in triplicates in clean sterile 250 Ml. High-Density Polyethene (HDPE) bottles previously cleaned with a detergent and rinsed with sampled water three times, and then filled to the brim at depth of about 0.4 meters at the point of discharge of effluents from five different locations within Oluyole industrial estate. Samples were collected using composite sampling from the following wastewater channels around 7UP, SUMAL, ZARTECH, WAW and INTROCOM industries within March, May and July. Water samples were transported to the analytical laboratory of the Biotechnology Centre, Federal University of Agriculture, Abeokuta, Nigeria. Five water quality parameters were selected to test for metals Arsenic, Chromium, Iron, Aluminum and Sodium. Sample preparation was carried out as described by [3]. $10 \mathrm{~mL}$ of each sample collected was taken in digestion tubes and added $3 \mathrm{~mL}$ concentrated $\mathrm{HNO}_{3}$ and subjected to digestion in a fume Cupboard for $1 \mathrm{~h}$ at $145^{\circ} \mathrm{C}$. Then $4 \mathrm{~mL}$ of $\mathrm{HClO}_{4}$ was added and heated to $240{ }^{\circ} \mathrm{C}$ for an additional hour. The tubes were cooled, and the digested samples were filtered through Whatman No. 42 filter paper and make up volume $50 \mathrm{~mL}$ and used for analysis following standard methods [11].

The preservation of collected samples was carried out according to reported standard methods [12]. Metals were analyzed with atomic absorption spectrophotometry (AAS) [Varian Model-AA240FS] after the wet-digestion of samples as previously described $[13,14]$.

\section{RESULTS AND DISCUSSION}

Water quality is not defined by the measurement of only one parameter. There is a range of chemical, physical and biological components that affect water quality. These variables are indications of how pollution may have altered the water quality [15]. Table 1 below is a selected list of WHO Standards for Permissible Limits of some selected 
parameters under consideration. While Figures 2 to 4 show the bar chart of measured water sample parameters for each location at specified times of the year.

Table 1. WHO Standards for permissible limits of some selected parameters.

\begin{tabular}{|c|c|c|}
\hline S/N & METAL & WHO (mg/L) \\
\hline 1. & ALUMINIUM & 0.30 \\
\hline 2. & ARSENIC & 0.01 \\
\hline 3. & CHROMIUM & 0.05 \\
\hline 4. & IRON & 0.3 \\
\hline 5. & SODIUM & 200 \\
\hline
\end{tabular}

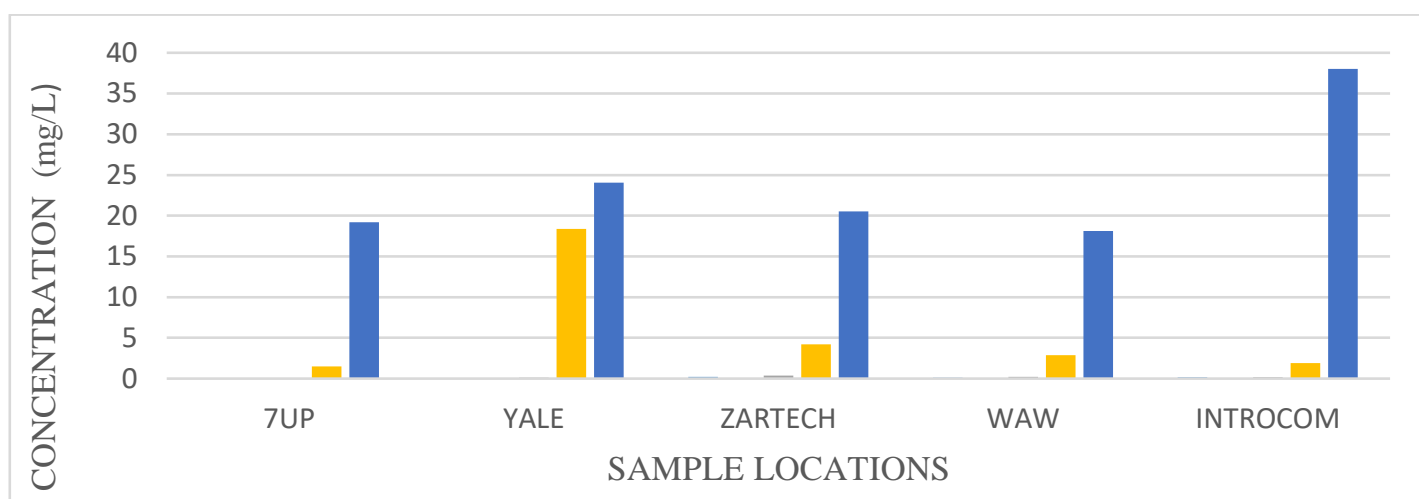

aLUMINIUM (mg/L) $\square \operatorname{ARSENIC~(mg/L)~} \square$ CHROMIUM (mg/L) $\square$ IRON (mg/L) $\square \operatorname{SODIUM~(mg/L)~}$

Fig. 2. Water quality results for march.

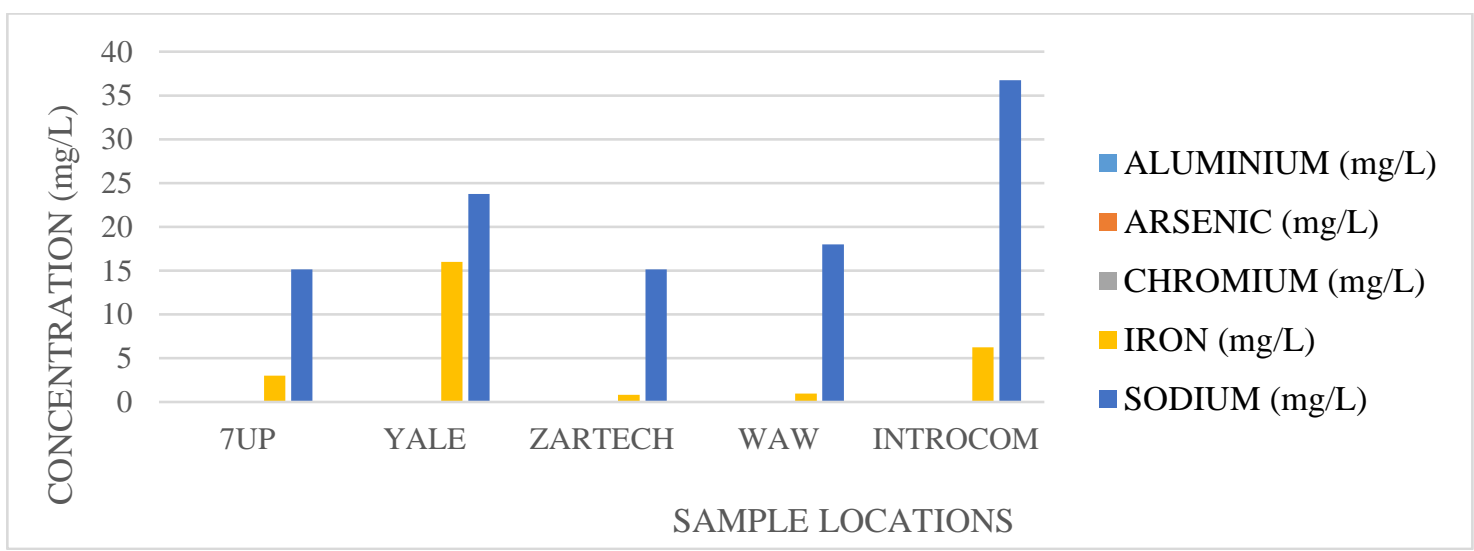

Fig. 3. Water quality results for may.

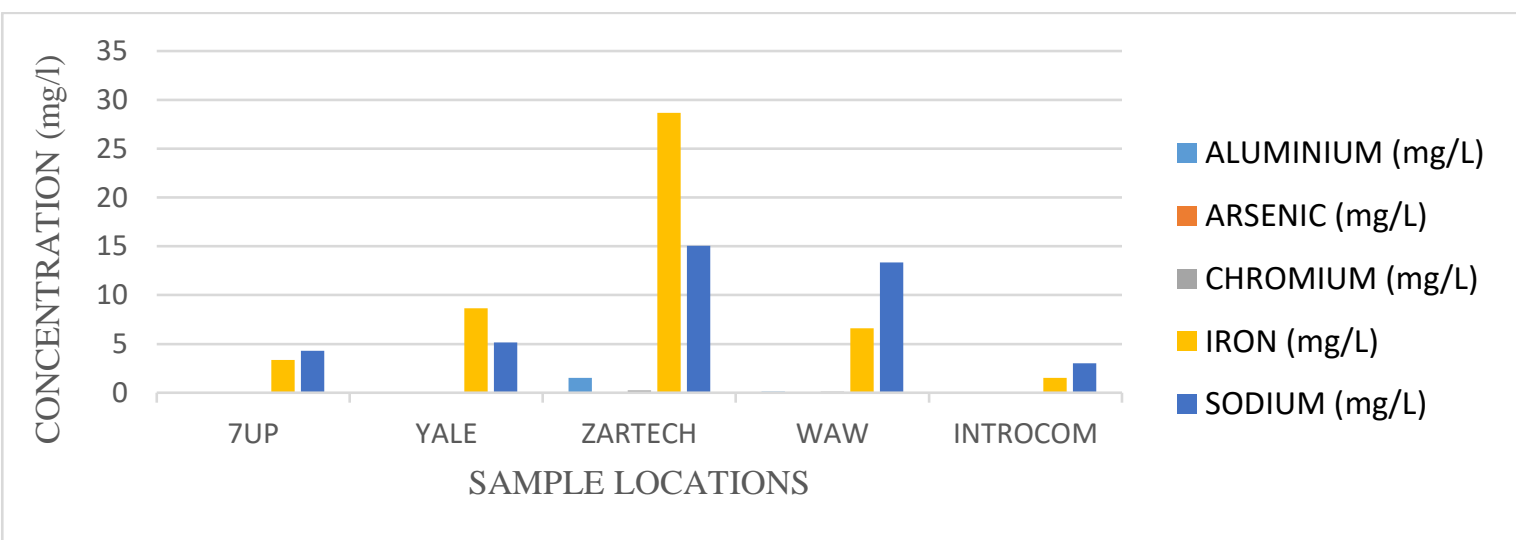

Fig. 4. Water quality results for july. 
Aluminium was not detected in the water samples collected from 7UP and YALE locations in March. It was not detected in May but was detected in ZARTECH and WAW locations in July with ZARTECH location having a value of $1.52 \mathrm{mg} / \mathrm{L}$ and thus exceeding WHO limits. Aluminium concentration in natural waters can vary due to different physicochemical and mineralogical factors. Dissolved concentrations of aluminium in waters with almost neutral $\mathrm{pH}$ values can range from 0.001 to $0.05 \mathrm{mg} / \mathrm{L}$ but rise to $0.5-1 \mathrm{mg} / \mathrm{L}$ in more acidic waters or water rich in organic matter [16]. Aluminium is also naturally present in foods or from aluminium-containing food additives. The use of aluminium cookware, utensils, and wrappings can increase the concentration of aluminium in food. Some foods naturally have a high concentration of aluminium and these include potatoes, certain types of edible vegetables and tea. Some processed dairy products and flour may be high in aluminium concentration if they contain aluminium-based food additives [16 - 18]. Another possible source of Aluminium is from Aluminium salts used in water treatment. All the samples detected with Aluminium concentration show that the values were below the maximum allowable limits of $0.3 \mathrm{mg} / \mathrm{L}$ as recommended by WHO.

Arsenic was not detected at all throughout the duration that the sampling was carried out at the sampling locations. Arsenic is a trace element found at variable concentrations in the atmosphere, soils and rocks, natural waters and organisms. It has a variety of uses including wood treatment to prevent rot and also in the common use of pesticides, paints, dyes, soap and drugs. The intake of large quantities of Arsenic pollutants leads to gastro internal symptoms, severe disturbances of the cardiovascular and central nervous systems and eventually death [19].

Chromium levels varied within the sample locations between March and July. There was no detection at 7UP sample location in March, WAW in May both YALE and INTROCOM locations in July. The elevated levels of Chromium in March may have resulted from various Industrial activities during the dry season when effluents may not be diluted. In the month of May, there was a significant reduction in Chromium concentration, and this may have resulted from the dilution arising from Precipitation during the rainy season. However, the highest values of $0.24 \mathrm{mg} / \mathrm{L}$ from ZARTECH sample location may have resulted from anthropological activities from the nearby industries. Apart from the not detected sample locations at various times of the recorded periods, Most of the water samples exceeded the maximum allowable limit of $0.05 \mathrm{mg} / \mathrm{L}$ as recommended by WHO. Most chromium compounds are carcinogenic, long exposure may cause kidney, liver and nerve damage [20]. Thus, those sample locations with elevated Chromium levels are an indication of unsafe Public health conditions around the flowing rivers.

The maximum and minimum values of Iron recorded respectively in March, May and July were $18.36 \mathrm{mg} / \mathrm{L}$ and $1.52 \mathrm{mg} / \mathrm{L}, 16.02 \mathrm{mg} / \mathrm{L}$ and $0.81 \mathrm{mg} / \mathrm{L}$ and $28.68 \mathrm{mg} / \mathrm{L}$ and $3.34 \mathrm{mg} / \mathrm{L}$. YALE sample location recorded the maximum values twice in March and May while ZARTECH recorded the highest and overall maximum concentration levels. This hike in Iron concentration levels may have resulted from both Industrial and natural sources due also to the influence of weather changes. All the samples collected and tested for Iron showed that the maximum allowable limit of $0.3 \mathrm{mg} / \mathrm{L}$ as recommended by WHO were exceeded. According to [21] the concentration of iron above $1.0 \mathrm{mg} / \mathrm{L}$ can cause ill health such as gastrointestinal irritation. The concentration of iron in rivers above the allowable limit can adversely affect animals' chances of survival, growth and reproduction due to toxicity of iron compounds.

The maximum and minimum values of Sodium detected in water samples in March, May and July respectively are $38.02 \mathrm{mg} / \mathrm{L}$ and $18.12 \mathrm{mg} / \mathrm{L}, 36.72 \mathrm{mg} / \mathrm{L}$ and $15.15 \mathrm{mg} / \mathrm{L}$ and $15.05 \mathrm{mg} / \mathrm{L}$ and $4.30 \mathrm{mg} / \mathrm{L}$. All samples collected fell below the maximum permissible limit of $200 \mathrm{mg} / \mathrm{L}$ as recommended by WHO [16].

Water quality is not defined by the measurement of only one parameter. There is a range of chemical, physical and biological components that affect water quality. These variables are indications of how pollution may have altered the water quality [15].

\section{CONCLUSION}

The summary of the research indicates that Arsenic was not detected within the sample locations, Aluminium concentration was below WHO maximum allowable limit, most of the samples showed Chromium levels exceeding WHO standards, Iron varied in the different locations and at different duration with all of the samples exceeding the limits set by WHO. Sodium levels from the samples collected all fell below the limits set by WHO. 
There is a need for further investigation to be carried out in order to better evaluate the status of the river flowing around Oluyole estate as this same river is being utilized by residents further downstream for domestic and agricultural uses.

\section{REFERENCES}

[1] Zhang, Z., Wang, J.J., Ali, A., Delaune, R.D., Heavy metals and metalloid contamination in Louisiana Lake Pontchartrain Estuary along I-10 Bridge, Transport and Environment, vol. 44, 2016, p. 66-77.

[2] Jartun, M., Ottessen, R.T., Steinnes, E., Volden, T., Runoff of particle-bound pollutants from urban impervious surfaces studied by analysis of sediments from storm water traps, Science of the Total Environment, vol. 396, no. 2-3, 2008, p. 147-163.

[3] Kumar, I., Chopra, A.K., Monitoring of physico-chemical and microbiological characteristics of municipal wastewater at treatment plant, Haridwar City (Uttarakhand), India, Journal of Environmental Science and Technology, vol. 5, 2012, p. 109-118.

[4] Jamrah, A., A-Futaisi, A., Prathepar, S., Al-Harrasi, A., Evaluating greywater reuse potential for sustainable water resources management in Oman, Environmental Monitoring and Assessment, vol. 137, 2008, p. 315-327.

[5] Dickson, A., Fewkes, A., Water-saving potential of domestic water reuses systems using greywater and rainwater in combination, Water Science and Technology, vol. 39, 1989, p. 25-32.

[6] Lone, M.I., Saleem, S., Mahmood, T., Saifullah, K., Hussein, G., Heavy metal contents of vegetables irrigated by sewage/tubewell water, International Journal of Agriculture \& Biology vol. 5, 2003, p. 533-535.

[7] Ahmed, M.J., Uddin, M.N., Islam, M.N., Islam, M.S., Islam, M.F., Physico-chemical assessment of soil pollutants due to the ship breaking activities and its impact on the coastal zone of Chittagong, Bangladesh, European Chemical Bulletin, vol. 2, no. 12, 2013, p. 975-980.

[8] Rasel, H.M., Hasan, M.R., Ahmed, B., Miah, M.S.U., Investigation of soil and water salinity, its effect on crop production and adaptation strategy, International Journal of Water Resources and Environmental Engineering, vol. 5 no. 8,2013 , p. 475-481.

[9] Amol, M., Jadhav, I., Singare, P.U., Studies on water pollution due to toxic metals in Ulhas River flowing along with the Dombivli City of Mumbai, India, International Letters of Natural Sciences, vol. 38, 2015, p. 66-76. [10] Admoroti C.M.A., Standard methods for wastewater and effluents analysis, Foludex Press Ltd., Ibadan, Nigeria, 1996.

[11] APHA, Standard methods for the examination of water and wastewater, $19^{\text {th }}$ Edn., American Public Health Association, Washington DC., USA, 1999.

[12] Cleseeri, L.S., Greenberg, A.E., Eaton, A.D. American Public Health Association, 17 ${ }^{\text {th }}$ Edn, Washington DC, 1989.

[13] Ebdon, L., Evans, E.H., Fisher, A., Hill, S.J., An introduction to analytical atomic spectrometry, John Wiley and Sons Ltd., England, 1998.

[14] Ikenaka, Y., Shouta., M.M.N., Kaampwe, M., Kennedy, C., Hiroki, T., Naoharu, M., Mayumi, I., Heavy metal contamination of soil and sediment in Zambia, African Journal of Environmental Science and Technology, vol. 4, no. 11, 2010, p. 729-739.

[15] Hisseien, A.A., Richard, K., Tchadanaye, N.M., Physico-chemical analysis of Logone River water at Moundou City in Southern Chad, International Journal of Biological and Chemical Science, vol. 9, no. 3, 2015 , p. 1654-1664.

[16] World Health Organization, International Programme on Chemical Safety, Environmental Health Criteria 194, 1997.

[17] Aluminium in toxicological evaluation of certain food additives and contaminants, Thirty-third meeting of the Joint FAO/WHO Expert Committee on Food Additives, Geneva, World Health Organization, 1989, p. 113 154.

[18] Pennington, J.A., Schoen, S.A., Estimates of dietary exposure to aluminium, Food Additives and Contaminants, vol. 12, no. 1, 1995, p. 119-128.

[19] Biney, C., Amuzu, A.T., Calamari, T.D., A Review of heavy metals in the African aquatic environment,Ecotoxicology and Environmental Safety, vol. 28, no. 2, 1994, p. 134-159.

[20] Aremu, D., Olaswuyi, F., Metshitsuka, S., Sridhar, K., Heavy metal analysis of groundwater from Warri, Nigeria International Journal of Environmental Health Research, vol. 12, 2000, p. 61-72.

[21] Nriagu, J.O., Lead in soils, sediments and major rock types, The Biogeochemistry of Lead in the Environment, 2008, p. 15-72. 